\title{
First Report of Congenital Adrenal Cysts and Pheochromocytoma in a Patient with Mosaic Genome-wide Paternal Uniparental Disomy
}

\section{Mary White ${ }^{1,2}$, George McGillivray ${ }^{3}$, Sue M White ${ }^{3,4}$, Margaret R Zacharin ${ }^{1,4}$}

${ }^{1}$ Department of Endocrinology \& Diabetes at The Royal Children's Hospital, Parkville, Melbourne, Australia; ${ }^{2}$ Department of Paediatric and Adolescent Endocrinology \& Diabetes, Monash Medical Centre, Clayton, Melbourne; ${ }^{3}$ Victorian Clinical Genetics Services, Murdoch Childrens Research Institute, Melbourne Australia; ${ }^{4}$ Department of Paediatrics, University of Melbourne, Melbourne, Australia

\section{Corresponding author}

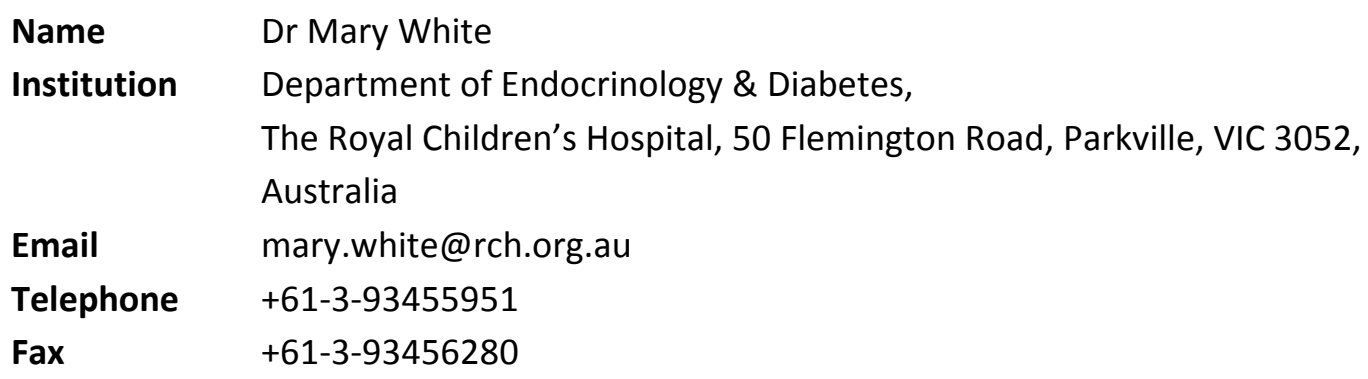

Keywords: Genome-wide paternal uniparental disomy - patUPD - Beckwith-Wiedemann syndrome - BWS - pheochromocytoma - congenital adrenal cysts

TO THE EDITOR,

Mosaicism for genome-wide paternal uniparental disomy (MGWpatUPD), also known as biparental/androgenetic mosaicism, is thought to be the result of complex early embryonic events following a normal conception. The resulting phenotype may be complex and highly variable. Descriptions of the 10 individuals with MGWpatUPD reported in the literature to date have all included features consistent with Beckwith-Wiedemann syndrome (BWS) or its associated Wilms tumor as the presenting clinical diagnoses [Bertoin et al., 2015; Gogiel et al., 2013]. Individuals may demonstrate features consistent additional imprinting disorders [Darcy et al., 2015; Gogiel et al., 2013; Inbar-Feigenberg et al., 2013; Yamazawa et al., 2011] and the increased risk of malignant tumors of embryonic origins seen in BWS is also characteristic of the MGWpatUPD phenotype [Bertoin et al., 2015; Gogiel et al., 2013].

MGWpatUPD is known to underlie placental mesenchymal dysplasia (PMD), previously felt to be a distinct and rare condition. PMD is characterized by cystic placental histology, intrauterine growth 
retardation and high rates of fetal demise in which BWS features were noted in up to one third of individuals [Jauniaux et al., 1997; Paradinas et al., 2001; Pham et al., 2006]. Wilson et al described 2 females diagnosed with PMD on the basis of cystic placental histology, and BWS-type phenotypes in whom confirmatory genetic analyses demonstrated MGWpatUPD [Wilson et al., 2008]. A clinical description of the first patient included typical BWS-like features and multiple chronic medical issues. Her course was further complicated at 8 years of age by the discovery of an asymptomatic unilateral cystic adrenal mass which was identified on routine abdominal ultrasound screening and confirmed histologically as a pheochromocytoma. Contralateral adrenalectomy was subsequently required for a second pheochromocytoma, rendering her steroid dependent. Both procedures were complicated by cerebrovascular events and severe hypertensive encephalopathy in the postoperative period. At the time, this was the first published description of pheochromocytoma in the MGWpatUPD setting, with only two previous reports of pheochromocytoma in the setting of BWS.

To further add to the literature base in MGWpatUPD, we hereby provide a clinical update on the second of the two females who presented with a unilateral pheochromocytoma subsequent to publication of the initial article [Wilson et al., 2008]. The clinical course of this girl (Patient 2 in the original description), now aged 14 years, is summarized below.

As the only child, naturally conceived, of non-consanguineous parents, preterm rupture of membranes preceded delivery at $29+6$ weeks gestation. The infant had a small umbilical hernia and hepatomegaly but no other phenotypic features of BWS at birth. Severe hyperinsulinism within hours of delivery ultimately necessitated a subtotal pancreatectomy which was performed at age 6 weeks. Hemihyperplasia with limb length discrepancy developed by 10 months of age. Hepatoblastoma at age 18 months required partial hepatectomy.

Antenatal sonography at 18,22 , and 28 weeks gestation had documented bilateral cystic adrenomegaly which appeared to have regressed on postnatal imaging by 5 months of age. During subsequent screening which was prolonged beyond the standard timeframe at her parents' request, 
a unilateral asymptomatic right sided adrenal cystic lesion was noted at age 11 years which demonstrated no appreciable uptake on targeted MIBG imaging and no specific diagnostic features on serial MRI. Over 12 months of surveillance the lesion increased in size to a dimension of $3.7 \times 3.1$ $x 3.6 \mathrm{~cm}$ in association with progressive elevations in noradrenaline and dopamine secretion on serial urinary and serum catecholamine analyses. Pheochromocytoma was confirmed after an uneventful adrenalectomy. Regular surveillance for recurrence or development of a second contralateral lesion is ongoing. No evidence of pheochromocytoma was demonstrated following targeted radiological investigations following the recent detection of mild elevations in plasma and urinary normetanephrine.

Pheochromocytomas in the pediatric population are most commonly identified within high risk genetic conditions such as von Hippel Lindau syndrome, multiple endocrine neoplasia syndrome type 2, neurofibromatosis type 1 and germline mutations of the succinate dehydrogenase subunits [Neumann et al., 2002]. Adrenal anomalies and adrenomegaly are inherent to the BWS phenotype [Beckwith J.B. 1969; Wiedemann 1964] and pheochromocytomas, while infrequent, are reported to comprise a very small percentage of tumors in this condition [Lapunzina 2005]. Radiological screening guidelines mainly focus on early identification of the most common tumors, hepatoblastoma and Wilms tumors. It is generally accepted that radiological screening is not typically warranted beyond the first decade of life in BWS [Teplick et al., 2011].

In addition to MGWpatUPD, one further condition, namely isolated hemihyperplasia (IH), has features overlapping with BWS and also carries this increased risk of malignancy. IH is a congenital growth disorder where the majority of affected individuals have no identified genetic etiology or underlying methylation defects at 11p15 [Clericuzio and Martin 2009]. However a higher tumor risk is seen in a minority of individuals who do demonstrate abnormalities in this region [Hoyme et al., 1998; Shuman et al., 2006]. A review of the available literature identified only 7 previous case reports of pheochromocytoma occurring up to the age of 20 years in any of BWS ( $n=2$, both 
bilateral) [Baldisserotto et al., 2005; Bemurat et al., 2002], IH ( $n=4)$ [Kalish et al., 2013; Pikilidou et al., 2014; Schnakenburg et al., 1976; van den Akker et al., 2002] and MGWpatUPD ( $n=1$, bilateral) [Wilson et al., 2008] which are summarized in Table I. The relative risk of pheochromocytoma in MGWpatUPD versus isolated 11p15 patUPD syndromes is not clear from the knowledge base to date. However there is the suggestion that the former may be associated with a particularly high predisposition, possibly due to imprinting defects at multiple loci [Bertoin et al., 2015; Gogiel et al., 2013]. In addition, it is conceivable that the phenotypes of some individuals with atypical features of 11 15 patUPD may in fact be attributable to MGWpatUPD which is more readily detected with contemporary genome-wide techniques. MGWpatUPD may still be underdiagnosed if analysis is restricted to the 11p15 region [Inbar-Feigenberg et al., 2013; Yamazawa et al., 2011]. Therefore it may be prudent to include whole genome analyses as standard in individuals with atypical BWS or IH phenotypes with confirmed 11p15 patUPD. This is the first report of pheochromocytoma in an individual who was noted to have had congenital adrenal cysts in one of these entities. Outcomes in 17 individuals with clinical diagnoses of BWS or IH have previously been described, in whom adrenal cysts were surgically removed in the neonatal period for 11 cases [Akata et al., 1997; McCauley et al., 1991; Merrot et al., 2004; Taide et al., 2010; Walton et al., 1991], with conservative management of the remaining 6 individuals [Anoop and Anjay 2004; Ciftci et al., 1997; Gocmen et al., 2005; Rahmah et al., 2004; Teh and Ong 2007; Zenker et al., 1999], Table IS. A contralateral adrenal adenoma developed at 8 months of age in one individual [McCauley et al., 1991] but no other adrenal pathology was reported at follow up. Non-adrenal sequelae (hepatoblastoma and Wilms tumor) were subsequently noted in two individuals [McCauley et al., 1991; Teh and Ong 2007]. On the basis of these reports it is not unreasonable to generally consider these congenital adrenal cysts to be benign lesions. However, given the fact that the natural history of the majority of reported lesions was attenuated by surgical removal in the neonatal period, this may not be a correct assumption. We may speculate them to be precursors of future adrenal pathologies, warranting long term surveillance beyond the time of apparent resolution. An increased awareness of the clinical 
course of individuals with MGWpatUPD may have implications for counselling and clinical surveillance, particularly if antecedent adrenal cystic lesions have been identified. Conservative management of these lesions in infancy may be considered after exclusion of neuroblastoma. However careful and continued radiological screening is necessary, and may be appropriate beyond the standard recommended BWS-type screening protocols in conditions with MGWpatUPD and loss of maternal methylation in the $11 \mathrm{p} 15$ region. Given that pheochromocytomas in both of these populations have now been reported to occur up until the third decade of life[Bemurat et al., 2002], long term follow up into adulthood is warranted. Ongoing surveillance should, at a minimum, encompass regular blood pressure measurement and periodic ultrasonography, with targeted investigations if an adrenal lesion is detected.

This updated review of the reported cases of congenital adrenal cysts and pheochromocytoma in MGWpatUPD serves to raise awareness among clinicians and geneticists alike to facilitate appropriate follow up strategies for individuals with this uncommon condition.

\section{References}

Akata D, Haliloglu M, Ozmen MN, Akhan O. 1997. Bilateral cystic adrenal masses in the neonate associated with the incomplete form of Beckwith-Wiedemann syndrome. Pediatr Radiol 27(1):1-2. Anoop P, Anjay MA. 2004. Bilateral benign haemorrhagic adrenal cysts in Beckwith-Wiedemann syndrome: case report. East Afr Med J 81(1):59-60.

Baldisserotto M, Peletti AB, Angelo de Araujo M, Pertence AP, Dora MD, Maciel EO, Gaiger AM. 2005. Beckwith-Wiedemann syndrome and bilateral adrenal pheochromocytoma: sonography and MRI findings. Pediatr Radiol 35(11):1132-1134.

Beckwith J.B. 1969. Macroglossia, omphalocele, adrenal cytomegaly, gigantism, and hyperplastic visceromegaly. Birth Defects Orig Art Ser 2:188-196. 
Bemurat L, Gosse P, Ballanger P, Tauzin-Fin P, Barat P, Lacombe D, Lemetayer P, Clementy J. 2002.

Successful laparoscopic operation of bilateral pheochromocytoma in a patient with BeckwithWiedemann syndrome. J Hum Hypertens 16(4):281-284.

Bertoin F, Letouze E, Grignani P, Patey M, Rossignol S, Libe R, Pasqual C, Lardiere-Deguelte S, Hoeffel-Fornes C, Gaillard D, Previdere C, Delemer B, Lalli E. 2015. Genome-wide paternal uniparental disomy as a cause of Beckwith-Wiedemann syndrome associated with recurrent virilizing adrenocortical tumors. Horm Metab Res 47(7):497-503.

Ciftci AO, Salman AB, Tanyel FC, Hicsonmez A. 1997. Bilateral multiple adrenal pseudocysts associated with incomplete Beckwith-Wiedemann Syndrome. J Pediatr Surg 32(9):1388-1390. Clericuzio CL, Martin RA. 2009. Diagnostic criteria and tumor screening for individuals with isolated hemihyperplasia. Genet Med 11(3):220-222.

Darcy D, Atwal PS, Angell C, Gadi I, Wallerstein R. 2015. Mosaic paternal genome-wide uniparental isodisomy with down syndrome. Am J Med Genet A 167a(10):2463-2469.

Gocmen R, Basaran C, Karcaaltincaba M, Cinar A, Yurdakok M, Akata D, Haliloglu M. 2005. Bilateral hemorrhagic adrenal cysts in an incomplete form of Beckwith-Wiedemann syndrome: MRI and prenatal US findings. Abdom Imaging 30(6):786-789.

Gogiel M, Begemann M, Spengler S, Soellner L, Goretzlehner U, Eggermann T, Strobl-Wildemann G. 2013. Genome-wide paternal uniparental disomy mosaicism in a woman with Beckwith-Wiedemann syndrome and ovarian steroid cell tumor. Eur J Hum Genet 21(7):788-791.

Hoyme HE, Seaver LH, Jones KL, Procopio F, Crooks W, Feingold M. 1998. Isolated hemihyperplasia (hemihypertrophy): report of a prospective multicenter study of the incidence of neoplasia and review. Am J Med Genet 79(4):274-278.

Inbar-Feigenberg M, Choufani S, Cytrynbaum C, Chen YA, Steele L, Shuman C, Ray PN, Weksberg R. 2013. Mosaicism for genome-wide paternal uniparental disomy with features of multiple imprinting disorders: diagnostic and management issues. Am J Med Genet A 161a(1):13-20. 
Jauniaux E, Nicolaides KH, Hustin J. 1997. Perinatal features associated with placental mesenchymal dysplasia. Placenta 18(8):701-706.

Kaiser-Rogers KA, McFadden DE, Livasy CA, Dansereau J, Jiang R, Knops JF, Lefebvre L, Rao KW, Robinson WP. 2006. Androgenetic/biparental mosaicism causes placental mesenchymal dysplasia. J Med Genet 43(2):187-192.

Kalish JM, Conlin LK, Mostoufi-Moab S, Wilkens AB, Mulchandani S, Zelley K, Kowalski M, Bhatti TR, Russo P, Mattei P, Mackenzie WG, LiVolsi V, Nichols KE, Biegel JA, Spinner NB, Deardorff MA. 2013. Bilateral pheochromocytomas, hemihyperplasia, and subtle somatic mosaicism: the importance of detecting low-level uniparental disomy. Am J Med Genet A 161A(5):993-1001.

Lapunzina P. 2005. Risk of tumorigenesis in overgrowth syndromes: a comprehensive review. Am J Med Genet C Semin Med Genet 137C(1):53-71.

McCauley RG, Beckwith JB, Elias ER, Faerber EN, Prewitt LH, Jr., Berdon WE. 1991. Benign hemorrhagic adrenocortical macrocysts in Beckwith-Wiedemann syndrome. AJR Am J Roentgenol 157(3):549-552.

Merrot T, Walz J, Anastasescu R, Chaumoitre K, D'Ercole C. 2004. Prenatally detected cystic adrenal mass associated with Beckwith-Wiedemann syndrome. Fetal Diagn Ther 19(6):465-469.

Neumann HP, Bausch B, McWhinney SR, Bender BU, Gimm O, Franke G, Schipper J, Klisch J, Altehoefer C, Zerres K, Januszewicz A, Eng C, Smith WM, Munk R, Manz T, Glaesker S, Apel TW, Treier M, Reineke M, Walz MK, Hoang-Vu C, Brauckhoff M, Klein-Franke A, Klose P, Schmidt H, Maier-Woelfle M, Peczkowska M, Szmigielski C, Eng C. 2002. Germ-line mutations in nonsyndromic pheochromocytoma. N Engl J Med 346(19):1459-1466.

Paradinas FJ, Sebire NJ, Fisher RA, Rees HC, Foskett M, Seckl MJ, Newlands ES. 2001. Pseudo-partial moles: placental stem vessel hydrops and the association with Beckwith-Wiedemann syndrome and complete moles. Histopathology 39(5):447-454. 
Pham T, Steele J, Stayboldt C, Chan L, Benirschke K. 2006. Placental mesenchymal dysplasia is associated with high rates of intrauterine growth restriction and fetal demise: A report of 11 new cases and a review of the literature. Am J Clin Pathol 126(1):67-78.

Pikilidou M, Yavropoulou M, Katsounaros M. 2014. Recurrent benign adrenal pheochromocytomas associated with hemihypertrophy. Endocrinol Diabetes Metab Case Rep 2014:140041.

Rahmah R, Yong JF, Sharifa NA, Kuhnle U. 2004. Bilateral adrenal cysts and ectopic pancreatic tissue in Beckwith-Wiedemann syndrome: is a conservative approach acceptable? J Pediatr Endocrinol Metab 17(6):909-912.

Schnakenburg KV, Muller M, Dorner K, Harms D, Schwarze EW. 1976. Congenital hemihypertrophy and malignant giant pheochromocytoma - a previously undescribed coincidence. Eur J Pediatr 122(4):263-273.

Shuman C, Smith AC, Steele L, Ray PN, Clericuzio C, Zackai E, Parisi MA, Meadows AT, Kelly T, Tichauer D, Squire JA, Sadowski P, Weksberg R. 2006. Constitutional UPD for chromosome 11p15 in individuals with isolated hemihyperplasia is associated with high tumor risk and occurs following assisted reproductive technologies. Am J Med Genet A 140(14):1497-1503.

Taide DV, Bendre PS, Redkar R, Hambarde S. 2010. Adrenal masses associated with Beckwith Wiedemann syndrome in the newborn. Afr J Paediatr Surg 7(3):209-210.

Teh SH, Ong GB. 2007. Early presentation of right adrenal mass, hepatoblastoma and hepatic cavernous haemangioma in Beckwith-Wiedemann Syndrome. Med J Malaysia 62(4):345-346. Teplick A, Kowalski M, Biegel JA, Nichols KE. 2011. Educational paper: screening in cancer predisposition syndromes: guidelines for the general pediatrician. Eur J Pediatr 170(3):285-294. van den Akker EL, de Krijger RR, de Herder WW, Drop SL. 2002. Congenital hemihypertrophy and pheochromocytoma, not a coincidental combination? Eur J Pediatr 161(3):157-160.

Walton GR, Peng BC, Berdon WE, Collins MH, Hensle TW. 1991. Cystic adrenal masses in the neonate associated with hemihypertrophy and the relation to the Beckwith-Wiedemann syndrome. J Urol 146(2 ( Pt 2)):580-582. 
Wiedemann HR. 1964. Familial Malformation Complex with Umbilical Hernia and Macroglossia - A new syndrome? J Genet Hum 13:223-232.

Wilson M, Peters G, Bennetts B, McGillivray G, Wu ZH, Poon C, Algar E. 2008. The clinical phenotype of mosaicism for genome-wide paternal uniparental disomy: two new reports. Am J Med Genet A $146 \mathrm{~A}(2): 137-148$.

Yamazawa K, Nakabayashi K, Matsuoka K, Masubara K, Hata K, Horikawa R, Ogata T. 2011. Androgenetic/biparental mosaicism in a girl with Beckwith-Wiedemann syndrome-like and upd(14)pat-like phenotypes. J Hum Genet 56(1):91-93.

Zenker M, Schindler C, Kandler C, Hummer HP, Rupprecht T, Ries M. 1999. A macrosomic newborn with a cystic adrenal mass. Eur J Pediatr 158(3):261-263. 
Table I. Reports of phaeochromocytoma in BWS and related syndromes

\begin{tabular}{|c|c|c|c|c|c|c|}
\hline Citation & n & Phenotype & Genotype & Bilateral & Age at onset & $\begin{array}{l}\text { Congenital adrenal } \\
\text { cysts }\end{array}$ \\
\hline Schnakenburg et al., 1976 & 1 & $\begin{array}{l}\text { Isolated } \\
\text { hemihypertrophy }\end{array}$ & Not known & No & 12 & Not reported \\
\hline van den Akker et al., 2002 & 1 & $\begin{array}{l}\text { Isolated } \\
\text { hemihypertrophy }\end{array}$ & Not known & Yes & 19 years & Not reported \\
\hline Bemurat et al., 2002 & 1 & BWS & Not known & Yes & 20 & Not reported \\
\hline Baldisserotto et al., 2005 & 1 & BWS & Not known & Yes & 8 years & Not reported \\
\hline Wilson et al., 2008 & 1 & $\begin{array}{l}\text { Mosaic genome- } \\
\text { wide patUPD }\end{array}$ & $\begin{array}{l}\text { Mosaic genome-wide patUPD following an initial } \\
\text { finding of whole chromosome } 11 \text { patUPD; almost } \\
\text { complete loss of maternal methylation at } 11 \text { p15.5 }\end{array}$ & Yes & 8 years & None reported \\
\hline Kalish et al., 2013 & 1 & $\begin{array}{l}\text { Isolated } \\
\text { hemihypertrophy }\end{array}$ & $\begin{array}{l}\text { Normal clinical methylation testing for } 11 p .15 ; \text { SNP } \\
\text { array analysis of skin fibroblasts from the hyperplastic } \\
\text { limb side demonstrated } 5 \% \text { mosaic paternal UPD for } \\
11 p 15 . \text { Single-nucleotide polymorphism (SNP) array } \\
\text { analysis of phaeochromocytoma tissue demonstrated } \\
\text { mosaic deletions of } 8 p 12 p t e r, 21 q 21.1 q t e r, \\
22 q 11.23 q t e r ; \text { commonly seen in } \\
\text { phaeochromocytomas. In addition, mosaic } \\
11 p 15.3 p t e r \text { homozygosity was noted }\end{array}$ & Yes & 18 months & Not reported \\
\hline
\end{tabular}




\begin{tabular}{|l|l|l|l|l|l|l|}
\hline Pikilidou et al., 2014 & 1 & $\begin{array}{l}\text { Isolated } \\
\text { hemihypertophy }\end{array}$ & $\begin{array}{l}\text { No epigenetic alterations in 11p15.5, which included } \\
\text { investigation for hypomethylation at KCNQ1OT1 and } \\
\text { hypermethylation at ICR1. No 11p15.5 uniparental } \\
\text { disomy (UPD) was found }\end{array}$ & Yes & 6 years & Not reported \\
\hline Current case & 1 & $\begin{array}{l}\text { Mosaic genome- } \\
\text { wide patUPD }\end{array}$ & $\begin{array}{l}\text { Mosaic genome-widepatUPD; partial loss of maternal } \\
\text { methylation at 11p15.3 }\end{array}$ & No & 11 years & Yes \\
\hline
\end{tabular}

Table IS Reports of congenital adrenal cysts in BWS and related syndromes

\begin{tabular}{|l|l|l|l|l|l|}
\hline Citation & $\mathbf{n}$ & Phenotype & $\begin{array}{l}\text { Hemorrhagic } \\
\text { component }\end{array}$ & Outcome & Associated tumors \\
\hline Walton et al., 1991 & 2 & $\begin{array}{l}\text { Isolated } \\
\text { hemihypertrophy }\end{array}$ & No & $\begin{array}{l}\text { Surgical removal; unilateral } \\
\text { benign adrenal cysts }\end{array}$ & None reported \\
\hline McCauley et al., 1991 & 6 & $\begin{array}{l}\text { 1) BWS: } \\
\text { hemihypertrophy, }\end{array}$ & Yes & $\begin{array}{l}\text { Surgical removal; benign } \\
\text { hemorrhagic macrocysts and }\end{array}$ \\
\hline
\end{tabular}




\begin{tabular}{|c|c|c|c|c|c|}
\hline & & $\begin{array}{l}\text { macroglossia, } \\
\text { umbilical hernia, } \\
\text { hepatomegaly }\end{array}$ & & adrenocortical cytomegaly & \\
\hline & & $\begin{array}{l}\text { 2) BWS,: } \\
\text { hemihypertrophy, } \\
\text { hemi-macroglossia, } \\
\text { hypoglycemia, } \\
\text { hepatomegaly }\end{array}$ & Yes & $\begin{array}{l}\text { Surgical removal; adrenocortical } \\
\text { cytomegaly, macrocystic changes } \\
\text { and acute hemorrhage, } \\
\text { microcystic changes in definitive } \\
\text { cortex }\end{array}$ & $\begin{array}{l}\text { Contralateral adrenal } \\
\text { adenoma removed at } 8 \\
\text { months of age }\end{array}$ \\
\hline & & $\begin{array}{l}\text { 3) BWS: hemi- } \\
\text { macroglossia, } \\
\text { hypoglycemia, } \\
\text { hepatomegaly }\end{array}$ & Yes & $\begin{array}{l}\text { Surgical removal; epithelium lined } \\
\text { cystic spaces, macrocysts } \\
\text { containing blood and adrenal } \\
\text { cytomegaly }\end{array}$ & None reported \\
\hline & & $\begin{array}{l}\text { 4) BWS: } \\
\text { hypoglycemia, } \\
\text { supraventricular } \\
\text { tachycardia, } \\
\text { hemihypertrophy from } \\
2 \text { months of age }\end{array}$ & Yes & $\begin{array}{l}\text { Surgical removal; multiple cysts, } \\
\text { interstitial hemorrhage and } \\
\text { adrenomegaly }\end{array}$ & $\begin{array}{l}\text { Wilms tumor at } 29 \text { months } \\
\text { of age with associated } \\
\text { mortality }\end{array}$ \\
\hline & & $\begin{array}{l}\text { 5) Isolated } \\
\text { hemihypertrophy }\end{array}$ & Yes & $\begin{array}{l}\text { Surgical removal; multiple } \\
\text { hemorrhagic cysts and } \\
\text { adrenomegaly }\end{array}$ & None reported \\
\hline & & $\begin{array}{l}\text { 6) Isolated } \\
\text { hemihypertrophy }\end{array}$ & Yes & $\begin{array}{l}\text { Surgical removal; multilocular } \\
\text { hemorrhagic cysts }\end{array}$ & None reported \\
\hline Akata et al., 1997 & 1 & $\begin{array}{l}\text { BWS: somatic } \\
\text { hypertrophy, }\end{array}$ & Yes & $\begin{array}{l}\text { Surgical removal of bilateral } \\
\text { hemorrhagic macrocysts and }\end{array}$ & None reported \\
\hline
\end{tabular}




\begin{tabular}{|c|c|c|c|c|c|}
\hline & & $\begin{array}{l}\text { hypertrophy, } \\
\text { macroglossia }\end{array}$ & & $\begin{array}{l}\text { hemorrhagic macrocysts and } \\
\text { cortical cytomegaly }\end{array}$ & \\
\hline Ciftci et al., 1997 & 1 & BWS & No & $\begin{array}{l}\text { Exploratory laparotomy, adrenal } \\
\text { pseudocysts }\end{array}$ & None reported \\
\hline Zenker et al., 1999 & 1 & $\begin{array}{l}\text { BWS: Macrosomia, } \\
\text { hemihypertrophy, } \\
\text { hemi-macroglossia }\end{array}$ & No & Adrenal cysts & None reported \\
\hline Anoop and Anjay 2004 & 1 & $\begin{array}{l}\text { BWS: macrosomia, } \\
\text { macroglossia, } \\
\text { hepatosplenomegaly, } \\
\text { nephromegaly }\end{array}$ & Yes & $\begin{array}{l}\text { Resolution of bilateral adrenal } \\
\text { cysts on ultrasound, presumed to } \\
\text { be hemorrhagic }\end{array}$ & None reported \\
\hline Rahmah et al., 2004 & 1 & & No & Resolved within 24 months & $\begin{array}{l}\text { Ectopic pancreatic tissue, } \\
\text { surgically removed in } \\
\text { neonatal period }\end{array}$ \\
\hline Merrot et al., 2004 & 1 & BWS: Macrosomia & No & $\begin{array}{l}\text { Surgical removal; hemorrhagic } \\
\text { macrocysts and adrenocortical } \\
\text { cytomegaly }\end{array}$ & None reported \\
\hline Gocmen et al., 2005 & 1 & $\begin{array}{l}\text { BWS: mild } \\
\text { hemihypertrophy, } \\
\text { hemimacroglossia }\end{array}$ & Yes & $\begin{array}{l}\text { Decreased size on follow up } \\
\text { imaging at } 2 \text { months of age }\end{array}$ & None reported \\
\hline Teh and Ong 2007 & 1 & $\begin{array}{l}\text { BWS: macroglossia, } \\
\text { hemihypertrophy, } \\
\text { hepatosplenomegaly }\end{array}$ & No & $\begin{array}{l}\text { Conservative follow up with } \\
\text { US/CT and MRI imaging }\end{array}$ & $\begin{array}{l}\text { Hepatoblastoma at } 11 \\
\text { weeks of age }\end{array}$ \\
\hline
\end{tabular}




\begin{tabular}{|l|l|l|l|l|l|}
\hline Taide et al., 2010 & 1 & $\begin{array}{l}\text { Isolated } \\
\text { hemihypertrophy }\end{array}$ & Yes & $\begin{array}{l}\text { Surgical removal; benign cyst with } \\
\text { adrenal rests suggestive of } \\
\text { hemorrhagic cyst }\end{array}$ & None reported \\
\hline Current case & 1 & $\begin{array}{l}\text { PMD: umbilical hernia, } \\
\text { hypoglycemia, } \\
\text { hemihypertrophy from } \\
10 \text { months }\end{array}$ & No & Resolved by 5 months of age & $\begin{array}{l}\text { Hepatoblastoma at 18 } \\
\text { months of age, unilateral } \\
\text { pheochromocytoma at } \\
\text { age 11 }\end{array}$ \\
\hline
\end{tabular}




\section{University Library}

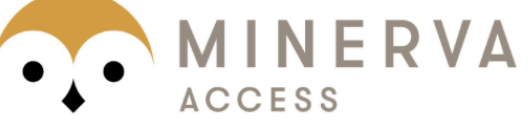

A gateway to Melbourne's research publications

Minerva Access is the Institutional Repository of The University of Melbourne

Author/s:

White, M;McGillivray, G;White, SM;Zacharin, MR

Title:

First Report of Congenital Adrenal Cysts and Pheochromocytoma in a Patient with Mosaic Genome-Wide Paternal Uniparental Disomy

Date:

2016-12-01

Citation:

White, M., McGillivray, G., White, S. M. \& Zacharin, M. R. (2016). First Report of Congenital Adrenal Cysts and Pheochromocytoma in a Patient with Mosaic Genome-Wide Paternal Uniparental Disomy. AMERICAN JOURNAL OF MEDICAL GENETICS PART A, 170 (12), pp.3352-3355. https://doi.org/10.1002/ajmg.a.37959.

Persistent Link:

http://hdl.handle.net/11343/291837 